\title{
EHMTI-0369. Migraine is a dysfunction of the mind - in networks creating reality
}

\author{
K Hougaard*, E Zunthe \\ From 4th European Headache and Migraine Trust International Congress: EHMTIC 2014 \\ Copenhagen, Denmark. 18-21 September 2014
}

\section{Introduction}

Thinking of migraine pathophysiology is today constrained by a post Wolff intellectual fixation with pain as the main migraine hallmark, and constrained by the rigid syndrome classification which excludes the understanding of other sufferings from the same dysfunction contributes to the creation of concepts. That fixedness is a significant obstacle to understand migraine as a general dysfunction of the brain.

\section{Method}

Knowledge of how the brain works on the system level has developed within the field of cognitive neuroscience. This knowledge is built on what brains does: It register the world, creates an understanding of reality, and acts according to goals. This approach is somewhat different from the classic neuron-approach of neurology, looking at what single neurons does.

We apply knowledge from cognitive neuroscience to present an understanding of what migraine is.

\section{Result}

Migraine is a dysfunction in network creation of what Bernard Baars describes as 'context' or 'frame'. Stanislas Dehaene is calling the same unconscious ongoing creation of a coherent workable reality 'precociousness'. This function is reflected in the P300 potentials.

\section{Conclusion}

We suggest a form to build knowledge about migraine brain dysfunction. We believe Albert Einstein knew an absolute and basic truth of how the human brain creates knowledge:

'It seems that the human mind has first to construct form independently before we can find them in things....

Neurology, Pun Hlaing International hospital, Yangon, Myanmar, Burma the truth [is] that knowledge cannot spring from experience alone, but only from a comparison of the inventions of the intellect with observed facts.
A. Einstein 1930
No conflict of interest.

Published: 18 September 2014

doi:10.1186/1129-2377-15-S1-L1

Cite this article as: Hougaard and Zunthe: EHMTI-0369. Migraine is a dysfunction of the mind - in networks creating reality. The Journal of Headache and Pain 2014 15(Suppl 1):L1.

\section{SpringerOpen ${ }^{\odot}$}

(0) 2014 Hougaard and Zunthe; licensee Springer. This is an Open Access article distributed under the terms of the Creative Commons Attribution License (http://creativecommons.org/licenses/by/2.0), which permits unrestricted use, distribution, and reproduction in any medium, provided the original work is properly cited.
Submit your manuscript to a SpringerOpen ${ }^{\circ}$ journal and benefit from:

$\checkmark$ Convenient online submission

- Rigorous peer review

- Immediate publication on acceptance

- Open access: articles freely available online

- High visibility within the field

- Retaining the copyright to your article

Submit your next manuscript at $\boldsymbol{~ s p r i n g e r o p e n . c o m ~}$ 